\title{
MENINGKATKAN KEMAMPUAN SISWA MEMBACA NOTASI MUSIK DENGAN MENGGUNAKAN METODE DEMONSTRASI DALAM PEMBELAJARAN SENI MUSIK
}

\author{
Deswarni ${ }^{*}$, Budiwirman ${ }^{2 *}$ \\ Program Studi Pendidikan Ilmu Pengetahuan Sosial Konsentrasi Pendidikan Seni dan Budaya \\ Program Pascasarjana \\ Universitas Negeri Padang \\ Jl. Prof. Dr. Hamta, Air Tawar Padang, Kel. Air Tawar Barat, Kec. Padang Utara, Kota Padang, Kode Pos 25171 \\ Sumatera Barat. Indonesia \\ Email:deswarniasrin@gmail.com
}

\begin{abstract}
Abstrak
Kemampuan membaca notasi musik dalam aktivitas siswa meliputi kegiatan memperhatikan guru dalam menerangkan pelajaran, bertanya, dan keberanian siswa maju kedepan kelas (Nasional, D.P. (2002), itusemua sangat kurang sekali ditemui dikelas XI IPS 1. Untukituperlu dilakukan suatu penelitian untuk mengetahui penyebapnya. Penelitian ini bertujuan untuk meningkatkan kemampuan siswa membaca notasi musik dalam pembelajaran seni musik, dengan target yang ingin dicapai adalah 75\%. Tindakan yang diterapkan adalah dengan menggunakan metode demonstrasi. Data dikumpulkan dengan bantuan instrument serta dilengkapi dengan observasi, selanjutnya diolah dengan teknik persentase untuk melihat kecendrungan-kecendrungan data setelah perlakuan diberikan. Jenis penelitian yang digunakan adalah penelitian tindakan kelas, sedang subjek penelitian ini adalah siswa kelas XI IPS 1 SMA Negeri 5 Pariaman dan perlakuan yang diberikan yaitu dengan menggunakan metode demonstrasi. Prosedur penelitian ini dilaksanakan dalam dua siklus, siklus I dilaksanakan 4 kali pertemuan dan siklus ke II dilaksanakan dalam 2 kali pertemuan dengan alokasi waktu satu kali pertemuan adalah 2 X 45 menit. Hasil penelitian dari data siklus I dalam meningkatkan kemampuan siswa membaca notasi musik dalam kegiatan aktifitas siswa dalam memperhatikan guru yang aktif $79,41 \%$, mengajukan pertanyaaan yang aktif mencapai $29,41 \%$, berani maju kedepan mencapai $44,11 \%$. Sedangkan kemampuan siswa membaca notasi musik mencapai 59,32\%. Data siklus II meningkatkan kemampuan siswa membaca notasi musik dalam kegiatan aktifitas siswa memperhatikan guru 82,35\%, mengajukan pertanyaaan $64,71 \%$, berani maju kedepan $70,59 \%$. Sedangkan kemampuan siswa dalam membaca notasi musik mencapai 75,50\%.Berdasarkan hasil pengolahan data dapat disimpulkan bahwa ada pengaruh tindakan yang diberikan terhadap peningkatan kemampuan siswa dalam membaca notasi musik dari siklus I ke siklus ke II meningkat menjadi 16,18\%.
\end{abstract}

Kata Kunci: notasi musik, metode demonstrasi.

\begin{abstract}
The ability to read music notation in student activities includes paying attention to the teacher in explaining the lesson, asking questions, and the courage of students to move forward in the classroom (National, DP (2002), all of them are very poorly found in class XI IPS 1. For this reason, a research is needed to find out. This study aims to improve students' ability to read music notation in learning music, with the target to be achieved is $75 \%$. The measures applied are using the demonstration method. Data is collected with the help of instruments and completed with observation, then processed with percentage techniques to see data trends after the treatment is given. This type of research is a classroom action research, while the subject of this study was a class XI IPS 1 student at SMA Negeri 5 Pariaman and the treatment given was using the demonstration method. The procedure of this research was carried out in two cycles, the first cycle was held 4 times and the second cycle was carried out in 2 meetings with the time allocation of one meeting was 2 X 45 minutes. The results of the study from the data cycle I in improving the ability of students to read music notation in the activities of students in paying attention to active teachers $79.41 \%$, asking active questions reached $29.41 \%$, dare to move forward reaching $44.11 \%$. While the ability of students to read music notation reached $32.17 \%$. Cycle II data improved the ability of students to read music notation in student activities paying attention to the teacher $82.35 \%$, asking questions $64.71 \%$, daring to go forward $70.59 \%$. While the ability of students to read music notation reaches $75.50 \%$. Based on the results of data processing, it can be concluded that there is an effect of the action given to the increase in students' ability to read music notation from cycle I to cycle II increasing to $16,18 \%$.
\end{abstract}


Keywords: music notation, demonstration method.

\section{PENDAHULUAN}

Yamaha musi Pembelajaran Seni Musik di Sekolah Menengah Atas SMA pada dasarnya diarahkan untuk mengembangkan kreatifitas bagi para siswa, sehingga terbentuk sikap apresiatif, kritis, dan proses kreatif dalam diri siswa. (Suharto, S. (2007).Selain itu pembelajaran Seni Musik juga berfungsi untuk menumbuh kembangkan sikap toleransi, demokrasi, beradap serta mampu menjalani kerukunan hidup dalam masyarakat bahkan melalui pembelajaran Seni Musik dapat meningkatkan kemampuan imajinatif, apresiasi karya seni, kepekaan rasa, keterampilan dan kemampuan berkreasi karya Seni musik dalam diri siswa dapat berkembang.

Untuk mencapai tujuan pembelajaran yang baik, guru merupakan unsur utama yang bertugas dan bertanggung jawab menjalankan kegiatan proses pembelajaran disekolah. Guru yang berkualitas adalah guru yang mampu mengubah anak yang pasif menjadi anak yang aktif, Oleh karena itu penelitian ini bertujuan untuk mengetahui apakah dengan menggunakan metode demonstrasi dapat meningkatkan kemampuan siswa membaca notasi balok dalam pembelajaran seni music

\section{KAJIAN TEORI}

\section{Seni Musik}

Musik da Pengertian musik dari The New Ensyclopedia of music and musicians, musik dalam arti umum adalah keindahan nada yang menimbulkan kepuasan estetis melalui indra pendengaran. Orang mengungkapkan perasaanya melalui bunyi (nada) atau ilmu penyusunan irama (ritmik) dan melodi sebagai unsurunsur dasarnya, sehingga terciptalah musik-musik yang indah. Namun bila diamati musik tidak selalu menggunakan nada-nada (melodius), tetapi juga menggunakan bunyi yang bukan nada. (Muttaqin, M. (2008). Dengan demikian dapat dikatakan juga bahwa musik adalah tatanan bunyi yang indah seperti yang diungkapkan oleh Sydney Lanier seorang penyair, musik adalah cinta yang sedang mencari sebuah kata. Dengan kata lain musik adalah curahan hati melalui bunyi sebagai perantara atau media.

\section{Metode Demonstrasi}

Metode demonstrasi adalah Cara penggunaan bahan pelajaran dengan memperagakan atau mempertunjukkan kepada siswa suatu proses, situasi atau benda-benda tertentu yang sedang dipelajari baik sebenarnya ataupun yang tiruan yang sering disertai dengan penjelasan lisan. Langkah pembelajaran metode demonstrasi sebagai berikut: 1). Mempersiapkan kegiatan: (a) menetapkan tujuantujuan yang akan dicapai; (b) menetapkan alatalat, bahan yang akan digunakan, dan sarana lain yang mendukung serta memeriksa ketersediaan alat; (c) mengadakan uji coba terlebih dahulu (guru) baik untuk alat-alat dan materi yang akan didemonstrasikan sehingga dapat ketetahui segala kemungkinan yang terjadi. 2). Melaksanakan kegiatan: (a) guru masuk kelas mengucapkan salam dan memberi motivasi siswa untuk melakukan kegiatan demonstrasi; (b) mendiskusikan bersama antara guru denga siswa mengenai langkahlangkah pelaksanaan, alat dan bahan yang digunakan serta hal-hal yang akan diamati dan dicatat hasil kegiatan demonstrasi; (c) guru di dibantu siswa melakukan demonstrasi, siswa mengamati dan mencatatnya dibawah bimbingan guru; (d) siswa menganalisis data pengamatan, menyimpulkan dan membuat laporan kegiatan secara kelompok (Kholifudin, M. Y. (2012).

Dengan metode demonstrasi, proses penerimaan siswa terhadap pelajaran akan lebih berkesan secara mendalam, sehingga membentuk pengertian dengan baik dan sempurna, siswa dapat mengganti dan memperhatikan apa yang diperlihatkan selama pelajaran berlangsung".

Metode demonstrasi baik digunakan untuk mendapatkan gambaran lebih jelas tentang hal-hal yang berhubungan dengan proses mengatur sesuatu, proses membuat sesuatu, proses menggunakan sesuatu, komponen-komponen yang membentuk sesuatu, membandingkan suatu cara dengan cara lain untuk menyelidiki atau melihat kebenaran sesuatu.

\section{METODE PENELITIAN}

Berdasarkan tujuan penelitian yang telah diungkapkan maka penelitian ini termasuk pada penelitian tindakan kelas, dimana peneliti mengadakan perlakuan (tindakan) tertentu berdasarkan masalah yang dihadapi dilapangan yang harus segera di atasi. Penelitian ini menggunakan satu kelompok subjek yang dikenakan perlakuan dalam jangka waktu tertentu. Perlakuan yang diberikan yaitu dengan menggunakan metode demonstrasi untuk meningkatkan kemampuan siswa dalam membaca notasi balok. Hasil dari penelitian adalah tes hasil belajar/tes unjuk kerja. Sebagai subjek penelitian adalah siswa kelas XI.IPS 1 SMA Negeri 5 Pariaman. Penelitian ini dilakukan dalam dua siklus. 


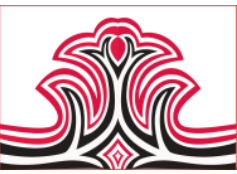

Pada siklus pertama dilakukan 4 kali pertemuan dan siklus kedua dilakukan 2 kali pertemuan. Alokasi waktu pada setiap kali pertemuan adalah 2 X 45 menit. Prosedur penelitian dibagi atas 4 bagian yaitu : rencana, tindakan, pengamatan, dan refleksi.

\section{HASIL DAN PEMBAHASAN}

\section{Hasil}

Data yang diperoleh pada siklus pertama dalam empat kali pertemuan yang teridiri dari kegiatan: memperhatikan, mengajukan pertanyaan, berani maju kedepan, dalam meningkatkan kemampuan siswa dalam membaca notasi balok sesuai dengan masingmasing indikator adalah sebagai berikut:

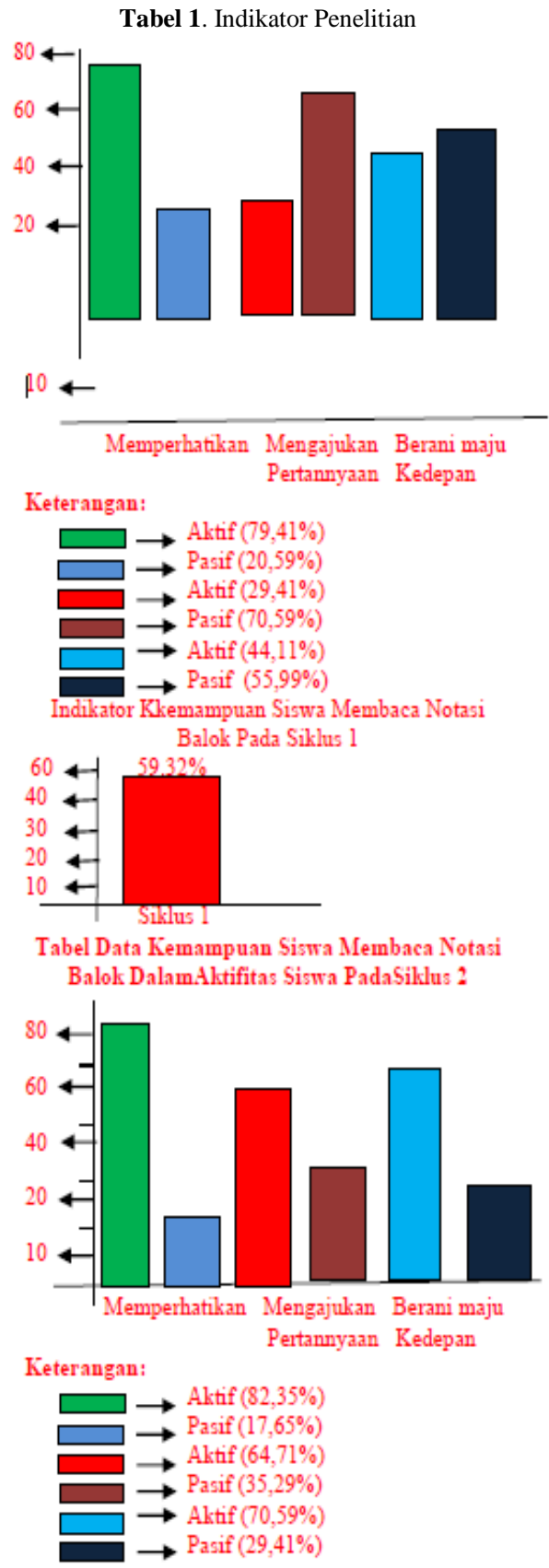

Gorga Jurnal Seni Rupa

Volume 08 Nomor 02 Juli-Desember 2019 p-ISSN: 2301-5942 | e-ISSN: 2580-2380

Indikator Klkemampuan Sisma Membaca Notasi Balok Pada Siklus ?

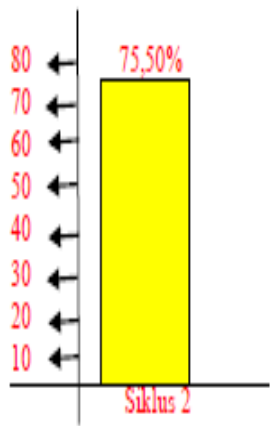

2.Pembahasan

Gaya bel Penggunaan metode demonstrasi selalu diikuti dengan eksperimen atau yang didemontrasikan. baik oleh guru maupun oleh siswa yang dianggap mampu untuk melakukan demonstrasi, tanpa diikuti dengan eksperimen tidak akan mencapai hasil yang efektif

Adapun Kerangka konseptual merupakan desain skematis yang dapat mengambarkan alur berfikir penulis dalam memaparkan masalah penelitian. (Jamiah, R., \& Surya, E. (2016). Melalui kerangka konseptual ini pula, para pembaca hasil penelitian dapat merangkai jalan fikiran dan alur pemaparan masalah, sehingga penelitian ini memenuhi kriteria ilmiah

Selain daripada itu penelitian ini menggunakan satu kelompok subjek yang dikenakan perlakuan dalam jangka waktu tertentu. Perlakuan yang diberikan yaitu dengan menggunakan metode demonstrasi untuk meningkatkan kemampuan siswa dalam membaca notasi balok. Hasil dari penelitian adalah tes hasil belajar/tes unjuk kerja.

\section{KESIMPULA DAN SARAN}

\section{Kesimpulan}

Ga1.Adanya peningkatan kemampuan siswa membaca notasi balok dengan menggunakan observasi yang menerapkan 2 siklus. Hal ini dapat dilihat dari aktifitas siswa dalam memperhatikan tergolong baik dari siklus I rata-rata $79,41 \%$ dan pada siklus II menjadi $82,35 \%$, aktifitas mengajukan pertannyaan tergolong cukup dari siklus I rata-rata $29,41 \%$ dan pada siklus II menjadi $64,71 \%$, aktifitas berani tampil kedepan tergolong cukup baik pada siklus I dengan rata-rata 44,11\% dan pada siklus II naik menjadi 70,59\%.

2.Peningkatan kemampuan siswa dalam membaca notasi balok di kelas XI IPS 1 SMA Negeri 5 Pariaman dilihat dari hasil observasi siklus I sampai siklus II tidak terlepas dari usaha guru dalam menerapkan metode demonstrasi. Hal ini terbukti dengan adanya peningkatan kemampuan siswa membaca notasi balok 


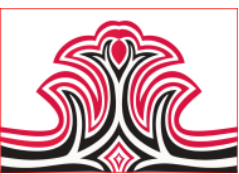

dari siklus I rata-rata 59,32\% dan pada siklus ke II mengalami kenaikan menjadi $75,50 \%$, kalau kita perhatikan dari pernyataan diatas telah terjadi peningkatan sebesar $16,18 \%$.

\section{Saran}

Pembelajar Mengacu kepada hasil penelitian, pembahasan dan kesimpulan yang ditarik maka dapat diajukan saran-saran sebagai berikut:

1. Penerapan tes unjuk kerja perlu lebih diintensifkan agar kebiasaan pembelajaran Seni Musik dengan mengunakan metode demonstrasi dapat lebih meningkat kemampuan siswa.

2. Agar aktivitas siswa dalam pembelajaran terpantau lebih baik, perlu dikembangkan instrumen yang benarbenar dapat mencakup seluruh aktivitas pembelajaran.

3. Bahan bacaan/sumber belajar Seni Budaya perlu diupayakan guru agar lebih sesuai dengan kompetensi yang dituntut kurikulum.

4. Perlu ada upaya-upaya terhadap peningkatan kemampuan guru-guru Seni Budaya dalam menyajikan pembelajaran secara interaktif, bermakna, menantang dan menyenangkan.

5. Agar pembelajaran Seni Budaya dilaksanakan berdasarkan kepada rencana pelaksanaan pembelajaran yang telah dipersiapkan sebelumnya, sehingga permasalahan kekurangan waktu penyajian dapat diatasi.

6. Perlu adanya sarana dan prasarana yang cukup,sehingga siswa lebih bisa memahami pelajaran dengan baik.

\section{DAFTAR RUJUKAN}

Jamiah, R., \& Surya, E. (2016). Pengaruh Model

Pembelajaran Talking Stick dengan Metode Math Magic terhadap Hasil Belajar Matematika pada Pokok Bahasan Kubus dan Balok di Kelas V SD Negeri 200211 Padang Sidimpuan. Axiom: Jurnal Pendidikan Matematika, 05(02),

Kholifudin, M.Y. (2012). Pembelajaran Fisika dengan Inkuiri Terbimbing Melalui Metode Eksperimen dan Demonstrasi Ditinjau dari Gaya Belajar Siswa. Yogyakarta: Prosiding Pertemuan Ilmiah XXVI HFI Jateng dan DIY.

Muttaqin, M. (2008). Seni Musik Klasik. Jakarta:

Direktorat Pembinaan Sekolah Menengah Kejuruan, Departemen Pendidikan Nasional.

Suharto, S. (2007). Pengembangan Materi dan

Kegiatan Pembelajarannya dalam Kurikulum Tingkat Satuan Pendidikan Bidang Seni
Gorga Jurnal Seni Rupa

Volume 08 Nomor 02 Juli-Desember 2019 p-ISSN: 2301-5942 | e-ISSN: 2580-2380

Musik. Hrmonia: Journal of Arts Research and Education, 08(03). 